\title{
The Mathematical Society of Serbia
}

\author{
Vladimir Mićić and Zoran Kadelburg (University of Belgrade, Serbia)
}

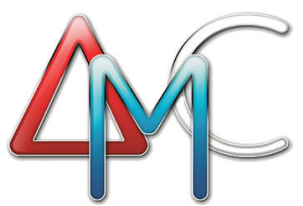

This year, the Mathematical Society of Serbia (MSS) (or Društvo Matematičara Srbije in Serbian) celebrated its 70th anniversary. But is this a long or short period?

\section{Preliminaries}

Liberation and restoration of the State of Serbia (in the first half of the 19th century) was followed by a serious movement toward educational and scientific development in the Principality as well as the Kingdom of Serbia. A number of Serbian mathematicians had PhDs from European scientific centres (e.g. Paris, Wien and Budapest) and provided an essential contribution to this development, which included the advancement of mathematical sciences at university. In the final decades of the 19 th century and the first four decades of the 20th century, one can see the presence of Serbian mathematicians (e.g. Mihailo Petrović, Nikola Saltikov, Anton Bilimović, Radivoje Kašanin, Tadija Pejović and Jovan Karamata) as authors of papers in scientific mathematical journals, as well as participants of the ICM and the ICME, with Mihailo Petrović present at the founding meeting of the IMU in 1920. In 1926, a "Mathematical Club" at the University of Belgrade was founded, directed by Anton Bilimović; it dealt with the scientific achievements and discussions of members, including their applications for publication in journals. In 1937, this club had turned into the "Yugoslav Mathematical Society", gathering together approximately 100 members with Tadija Pejović as its president.An additional list of mathematical publications, intended for secondary school students ("Matematički list") and researchers in mathematics ("Matematički vesnik"), as well as activities of the Union of Mathematics Students, complete this sketch of mathematical life in Serbia during the period before the Second World War.

\section{Foundation of the MSS - the first years}

The foundational meeting of the society took place on 4 January 1948 in Beograd; Tadija Pejović was elected as its first president. There was a basic decision to realise three parallel activities: scientific work in mathematics, mathematics education, and popularisation of mathematics. As

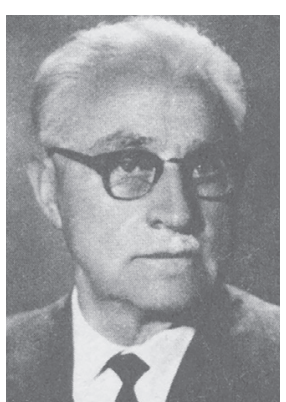

Tadija Pejović physicists were included, the same scheme was also projected for physics (till 1981). At the very beginning, the scientific journal Vesnik Društva matematičara $i$ fizičara Srbije was established and Jovan Karamata was named the editor-in-chief; its publication started in 1949. As Matematički Vesnik, it has been a permanent presence in the scientific life of Serbia since 1964. The MSS initiated the foundation of the Union of Yugoslav Societies of Mathematicians and Physicists (UYSMP) and organised the first Congress of Mathematicians and Physicists of Yugoslavia. These initiatives were realised in 1949 and, later on, UYSMP represented all the societies on international boards and organisations, including the IMU, the ICMI and the BMU (Balkan Mathematical Union). Publishing the nec-

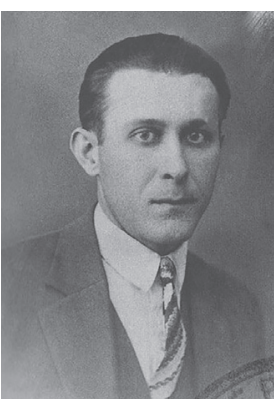

Jovan Karamata essary journals and other publica-

tions (intended for the whole country) was initiated and promptly realised. Nastava matematike i fizike, covering problems of education at all levels, has been published in Beograd since 1952 (it is now modified and entitled Nastava matematike).

\section{The years that followed}

The original scheme of MSS activities, enriched and modernised, has been preserved in subsequent years.

\section{Scientific section}

In the scientific domain, the MSS has been permanently present as a responsible standard-bearer in a wide range of activities (including international connections and collaboration), such as: publication of the scientific journal; regularly organised congresses of mathematicians; symposia and seminars (national and international) considering actual problems in several mathematical disciplines; organisation of a number of scientific sessions; and coordination of collaborations between various participants in the scientific life of the country (mathematical departments, institutes and other partners).

The scientific journal Matematički Vesnik mentioned in the introductory section has been in existence for 69 years (with 210 issues so far) and has been an important stage for the publication of original research papers, the presentation of new results and achievements in mathematical sciences and the provision (till 1980) of information about the activities of the MSS. The editorial board has been (and is) of international character, as is the majority of invited referees. The list of authors has varied from predominantly domestic to predominantly foreign authors; at present, it is somewhat balanced. The complete list of editors-in-chief is Jovan Karamata, Dragoljub Marković, Zlatko Mamuzić, Dušan Adnadjević, Zoran Kadelburg, Mila Mršević, Ljubiša Kočinac and Neda Bokan. The journal is available in electronic form and can be found at www.vesnik.math.rs.

Scientific meetings, organised by the MSS itself or by some other institution with an essential MSS contribution, can be classified into (a) national congresses (13 so far with the 14th in preparation), Yugoslav as well 
as Serbian, with significant international participation, and (b) international seminars and symposia. The latter have covered: Differential and Partial Differential Equations; Numerical Solution of Differential Equations; Coordination of Mathematics and Physics Instruction; the 5th Balkan Congress of Mathematicians; Topology and its Applications (five symposia); Complex Analysis and Applications (three symposia); and Mathematical Analysis and its Applications (two symposia with the third in preparation). One should take into account that the majority of these meetings were organised during the time of the Cold War (before 1990), a period when contact, even between scientists, was controlled and, in a way, extremely reduced. As Yugoslavia (and therefore Serbia) was a non-alignment country, we were able to invite colleagues from both sides of the "Iron Curtain" and to initiate creative official and private meetings and further collaboration. In the shortened list of foreign participants, one can recognise the names of numerous significant mathematicians of this period: L. Ahlfors, L. Aizenberg, P. S. Aleksandrov, T. Ando, M. Antonovskij, V.G. Boltjanskij, K. Borsuk, G. Choquet, R. Courant, A. Csaszar, W. Hengartner, G. Henkin, E. Hille, Y. Komatzu, I. Korevaar, W. Rudin, G. Sansone, W. Sierpinski, M.H. Stone, M. Vuorinen and V.A. Zorič. Since the 10th congress (Beograd 2001), the scientific committees of the congresses have awarded special prizes for young researchers (to Danko Jocić, Vladimir Dragović, Božidar Jovanović and Dragana Cvetković-Ilić).

Another in the range of scientific activities led by the MSS was a serious contribution to originating a number of "schools", characterising topics of mathematics achievement in Serbia, such as topology and set theory, complex analysis and distribution theory.

Particular thanks go to certain members of the MSS: Vojin Dajović, Djuro Kurepa, Konstantin Orlov, Zlatko Mamuzić, Bogoljub Stanković and Milica Ilić-Dajović, due to whose enthusiasm and essential contribution the

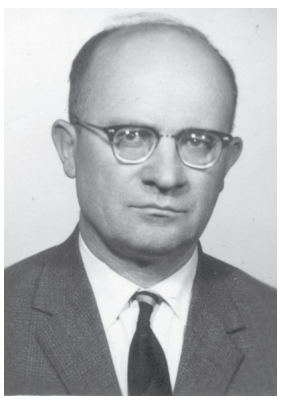

Vojin Dajović

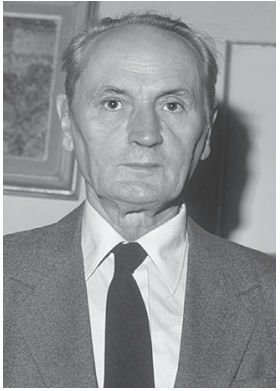

Djuro Kurepa meetings and activities mentioned have been successfully realised.

\section{Teaching section}

Systematic efforts toward improvement of teaching and learning in mathematics have been present in MSS activities from the very beginning. In the early 1960s, thanks to the initiative and personal devotion of Vojin Dajović, an official document of the state authorities was accepted containing explicit recommendations for "paying special care to the mathematics education and development of the mathematical culture". This was a strong impulse for general affirmation of mathematics. It has been followed by further confirmation of programmes with a sciencemathematical specialisation in high schools, including the foundation

in Beograd of a specialised Mathematical High School and an increase of interest in studying mathematics. The first steps introducing numerical methods and computer programming into the curricula of secondary schools and universities were made during these years, too.

Nastava matematike, the MSS Serbian language journal (and its bulletin) continued to be published, with the aim of including theoretical problems of learning and teaching practices in mathematics, the exchange of good practices, information about tendencies in mathematics educational practices around the world, etc. The list of editors of the journal over 65 years of mathematical life in Serbia is: Ivan Bandić, Djuro Kurepa, Milica Ilić-Dajović, Miroslav Živković, Milosav Marjanović, Vladimir Mićić and Zoran Kadelburg. The MSS scientific journal The Teaching of Mathematics was founded in 1998 for research papers in mathematics teaching and, over the past 20 years, has acquired wide support in Serbia and abroad. The international character of both the editorial board and the majority of invited referees can be taken as an additional guarantee of permanency. The complete list of editors is relatively short: Milosav Marjanović, Vladimir Mićić and Zoran Kadelburg. The active site of the journal is www.teaching.math.rs.

In the early 1960 s, traditional "state seminars for professional improvement of primary and secondary school mathematics teaching" were established (from the late 1980s also including informatics). Their programmes consist of a few plenary lectures, several special working sections and a number of master classes. In recent years, since the process of systematic licensing of teachers within the educational system has started, the character of these seminars has been, in some way, formalised and their role in the professional progress of mathematics and informatics teachers has been significantly improved. They are supplemented by regional seminars of similar character. The permanent increase in the number of master classes in informatics is evident.

\section{Popularisation section}

Ever since the founding of the MSS, systematic activities have been present for the identification, fostering and development of students, at all levels, who are gifted and interested in mathematics. A range of "out of the classroom" activities have been realised. Following the practice of mathematical societies and other institutions in many countries, the necessary literature was published and a system of competitions was organised. For secondary school students, the journal Tangenta has been published since 1995. The same function for primary school pupils was assigned to Matematički list, published in Beograd since 1967. These two journals have been accompanied by 55 issues of the series Materijali za mlade matematičare, which is intended for young mathematicians. At least twice a year, MSS organises a "Summer (Winter) school for young mathematicians", a kind of master class for interested students. They have been organised by MSS branches from mathematical centres of Serbia, the majority of them by the Valjevo branch and managed by Vojislav Andrić, the current president of the MSS. 
From the first unofficial competition for secondary school students (Beograd, 1958) to participation at the 7th IMO (Poland, 1963), the route was direct and prompt. This was similar for higher primary school pupils, aged between 9 and 15, who started with a Serbian competition in 1967. Their first participation in an international event took place in 1997 at the Junior Balkan Mathematical Olympiad, held in Beograd and organised by the MSS. Young mathematicians of Serbia, through the MSS, are regular participants of the famous international competition "Kangaroo without frontiers" (the number of participants has increased to 36,000 in 2018).

Thanks to its specific geopolitical position, the MSS, as the host of the 9th IMO (1967), was able to invite several countries from Western Europe to participate; with the presence of young mathematicians from the United Kingdom, France, Italy and Sweden, the IMO seized the opportunity for a mathematical competition with representation from more than just Eastern European countries. The next contribution of the MSS to the broadening of the IMO movement was realised in 1977, when the MSS, as host of the 19th IMO, invited mathematicians from some non-European countries; with the presence of young mathematicians from Algeria, Brazil and Cuba, the IMO turned into a worldwide event. These organisational steps were accompanied by some very good results for Serbian students at the IMOs, including 15 gold med- als, with Teodor von Burg achieving four of them, which resulted in him holding first position in the Hall of Fame of the IMO for several years.

The Mathematical Society of Serbia will continue all of its activities over the forthcoming years. In particular, in 2018, the 14th Serbian Mathematical Congress will be organised, the 35th Balkan Mathematical Olympiad will be held in Beograd and there will be an event marking the 150th anniversary of our great mathematician Mihailo Petrović.

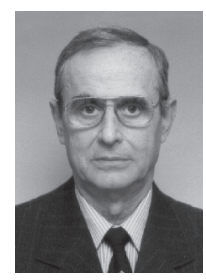

Vladimir Mićić (1936) [vladimic@mts.rs] is a professor of advanced engineering mathematics and didactics of mathematics at the University of Belgrade. He has been active with the MSS for 55 years. He is an ex-president of the society and is its first Honoured Member.

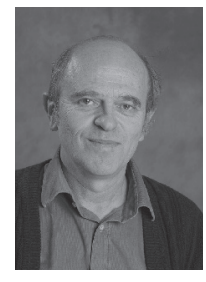

Zoran Kadelburg(1950) [kadelbur@matf. bg.ac.rs] is a professor of mathematical analysis and functional analysis and is an ExDean of the Faculty of Mathematics at the University of Belgrade. He has been involved in the complete range of MSS activities for 50 years and is an ex-president of the society. 